\title{
A Study of Mind Mapping in Elementary Islamic School: Effect of Motivation and Conceptual Understanding
}

\author{
Alfauzan Amin ${ }^{1, *}$, Mawardi Lubis ${ }^{1}$, Alimni $^{1}$, Saepudin $^{1}$, Jaenullah $^{2}$, Dwi Agus Kurniawan², \\ Meri Lestari ${ }^{1}$ \\ ${ }^{1}$ Faculty of Tarbiyah, Institute Agama Islam Negeri Bengkulu, Bengkulu, Indonesia \\ ${ }^{2}$ Faculty of Tarbiyah, Institut Agama Islam Negeri Almaarif Metrro, Lampung, Indonesia \\ ${ }^{3}$ Faculty of Teaching and Education, Universitas Jambi, Jambi, Indonesia
}

Received June 17, 2020; Revised August 21, 2020; Accepted September 11, 2020

\section{Cite This Paper in the following Citation Styles}

(a): [1] Alfauzan Amin, Mawardi Lubis, Alimni, Saepudin, Jaenullah, Dwi Agus Kurniawan, Meri Lestari, "A Study of Mind Mapping in Elementary Islamic School: Effect of Motivation and Conceptual Understanding," Universal Journal of Educational Research, Vol. 8, No. 11, pp. 5127-5136, 2020. DOI: 10.13189/ujer.2020.081112.

(b): Alfauzan Amin, Mawardi Lubis, Alimni, Saepudin, Jaenullah, Dwi Agus Kurniawan, Meri Lestari (2020). A Study of Mind Mapping in Elementary Islamic School: Effect of Motivation and Conceptual Understanding. Universal Journal of Educational Research, 8(11), 5127-5136. DOI: 10.13189/ujer.2020.081112.

Copyright $\odot 2020$ by authors, all rights reserved. Authors agree that this article remains permanently open access under the terms of the Creative Commons Attribution License 4.0 International License

\begin{abstract}
The purpose of this study is to see whether there is an influence between students' learning motivation and students' understanding of concepts in learning social science. This study uses a mixed research method with a sequential explanatory design. The sample used in this study consisted of two different regions, namely rural and urban areas in Bengkulu, with a total of 600 respondents from the Madrasah Ibtidaiyah (equivalent to Islamic elementary schools), where the breakdown was in urban areas of 300 respondents and rural 300 respondents. This study uses instruments in the form of questionnaires for motivation, MCQ, and semi-structured interviews, where the questionnaire used was developed by researchers and has been tested by relevant experts in their fields. From the explanation that the researcher has done, the results show that the learning motivation of the students plays a role in understanding the concept of students in the material, especially in the social study material. This mind mapping can solve existing problems, students are lazy, and students do not have a critical and coherent understanding, one of the solutions is using mind mapping, because by using mind mapping students have a continuous and continuous way of thinking. With good motivation, students have a willingness from within the individual and from outside the individual students to deepen a material. Students who have good motivation will be severe in looking for information about the material they want to explore in detail so that students can make maps the concept itself.
\end{abstract}

This is also evidenced by the influence shown by the sig value below 0.025 , and there is a contribution of student conceptual understanding of motivation by $72.5 \%$. Therefore, it is recommended to the principal and vice-principal in the curriculum field to urge teachers to provide innovation in their learning. The teacher must understand the method so that the creation of student-centered learning is under the applicable curriculum.

Keywords Conceptual Understanding, Learning, Motivation, Mind Mapping

\section{Introduction}

The human mind stores something that has been seen, heard, and felt. However, of all the advantages possessed by humans than other creatures, it certainly has weaknesses. The weakness of the human mind has been the inability to remember things in detail for a long time. When messages or information from new experiences comes, usually old messages or information are often forgotten. This does not only occur in older people who often experience senile disease (forgetfulness) and often occurs in all walks of life, including students [1, 2]. Indeed, humans are created with different abilities, including the ability to remember. 
Therefore, without taking notes or repeating to remember them, humans, in this case, students are only able to remember a small portion of the information they receive $[3,4]$. So, taking notes can improve memory. The learning process involves directly two essential elements of the teacher and students. The teacher is a source of knowledge and skills, while students are the recipients of knowledge and skills. In teaching and learning interactions in addition to being the process of handing over knowledge and skills, the process of planting values into students also takes place. So at the end of a process of teaching and learning interaction, at least three domains are the ultimate goal of the educational process, namely the cognitive domain (knowledge), the psychomotor domain (skills), and the affective domain (attitude and behavior) [5-7].

Therefore, teachers need to know the cognitive aspects of students (conceptualization) and the affective aspects (motivation to learn) in learning [8]. Understanding the concept is the ability of someone to understand or understand something after something is known or remembered, including the ability to capture the meaning of the material being studied, which is stated by describing the main contents of reading, or changing the data presented in certain forms to other forms. The communication may be in oral or written form, in verbal or symbolic form. Understanding is concerned with the essence of something, which is a form of understanding that causes someone to know what is being communicated $[9,10]$. Mathiassen \& Winkel (1996) gives a limitation that a concept is a unit of meaning that represents several objects that have the same characteristics [11]. The ability to capture meaning is like being able to express a material that is presented in a more understandable form, providing interpretation data and being able to apply concepts under its cognitive structure, especially in social studies learning. $[12,13]$.

Because in essence, social studies learning in the middle, high schools that are integrated (integrated) aim to make these subjects more meaningful for students so that the organization of subject matter/materials is adjusted to the environment, characteristics, and needs of students [14, 15]. That way, students can master the dimensions of learning in school, namely: mastering knowledge (knowledge), skills (skills), attitudes and values (attitudes and values), and acting (action) [16]. That way, we need an excellent concept of understanding by applying good learning strategies. Mind maps are a way that students use to help optimize both sides of the brain's ability by creating concepts or mapping ideas or thoughts from the subject matter with a combination of colors, pictures, and curved branches [17]. Mind maps use the brain's ability for visual recognition to get maximum results [18]. According to Davies (2011), mind mapping is divided into three types: syllabus mind maps, chapter mind maps, and paragraph mind maps [18], so that by using mind mapping, it can make it easier for students to understand a concept in a material.

Understanding the concepts possessed by students is inseparable from the learning strategies applied by the teacher in learning. Conceptually, the learning process is seen from a cognitive approach, not getting information from outside students, but as meaning to students through a process of assimilation and accommodation that leads to cognitive renewal. $[19,20]$. That process will give birth to understanding. The process of achieving and understanding student concepts is determined by the learning strategy chosen by the teacher. The process of thinking by discussing and arguing with peers will help clarify thinking, which ultimately results in more logical thinking [21-23].

In deepening the concept of material, attitude is one that must be considered. Especially on social studies material, because students who have a positive attitude will be different from students who do not have a preferred viewpoint during the process $[24,25]$. One that influences attitude is motivation. According to Syaiful (2020), in general, motivation means something that encourages action or action [26]. Motivation can be defined as the strength (energy) of people who have perseverance and enthusiasm in carrying out activities, both from within the individual (intrinsic motivation).

Furthermore, from extrinsic motivation, they like to get prizes and find their concept, making it easier for them to deepen the material they want. Students who have negative attitudes towards learning have less motivation for involvement in class. Likewise, students who have positive attitudes towards learning will have motivation for involvement in the class [27, 28], because having high motivation can lead to a good understanding of concepts to students. Students who have the right motivation will have a good understanding of the concept. By having the right motivation, students will be severely "in finding the information in detail and making a note of their own. The characteristics of students who have the self-motivation include these students being diligent in facing assignments, resilient in facing difficulties, more independent, able to defend their opinions, happy and able to solve problems they face [26].

Therefore, this study aims to determine whether there is an influence between students' conceptualization in social science learning and their learning motivation. With the following research questions:

1) How to grasp the concepts that are owned by students in learning, social science (geography, history, sociology, and economics)?

2) What motivation do students have during social science learning (geography, history, sociology, and economics)?

3) Is there an influence between the students' understanding of concepts and learning motivation in social science (geography, history, sociology, and economics)? 


\section{Materials and Methods}

\subsection{Research Design}

This research uses a mixed-methods approach. Martens (2010) "mixed methods can refer to the use of quantitative and qualitative data in answering research questions as well as being part of a more extensive research program and designed as a complement to provide information related to different methodological approaches [29]. The type used is sequential explanatory. Sequential explanatory research is a study where the initial data collection is quantitative, followed by qualitative data, which means that quantitative data is strengthened by the qualitative data obtained [30].

\subsection{Research Subject}

Where quantitative data was obtained through giving motivation questionnaires and MCQs for understanding students' concepts in social science learning (geography, history, economy, and sociology), then followed by qualitative activities, namely conducting interviews with students, this study used 600 Madras Ibtidaiyah students (equivalent to Islamic elementary schools) with details of 300 students coming from urban areas (182 male students and 118 female students) and 300 students from rural areas (182 male students and 118 female students) using total sampling techniques. The total sampling technique is an example of a collection technique that uses the whole population [31], then interviews only 40 students who are willing to do the interview. The instruments in this study used questionnaires and interviews. The questionnaire is a list of questions given to other people willing to answer (the respondents) according to user requests [32].

\subsection{Research Instrument}

In the first data collection process, because it uses the type of sequential explanation, the first data obtained is quantitative data through a motivational questionnaire and multiple-choice questions for students' understanding of concepts in social science learning (geography, history, economy, and sociology). Researchers developed the questionnaire in this study, and for the learning motivation questionnaire had 23 valid statements with a Cronbach alpha value of 0.73 questionnaires, this uses the Likert Scale 4. After the quantitative activities are carried out, it is continued with qualitative activities, namely conducting semi-structured interviews to confirm the quantitative results that have been conducted. Then to process SPSS 21 data used to look for descriptive statistics to see quantitative data, while for qualitative data using Miles \& Huberman, namely reducing data, display data, and conclusions [33]. Descriptive statistics are presented in summary frequencies, such as mean, mode, median, minimum, maximum, and standard deviation [32]. In this study, the descriptive statistics used are mean, min, max, and category.

Below is a category of motivation in table 1 , and understanding of concepts in learning, social science in table 2 , among others, very good, good, not good, and very not good.

Table 1. Categories of student motivation

\begin{tabular}{cc}
\hline Category & Motivation \\
\hline Very Not Good & $23.0-40.2$ \\
Not Good & $40.3-57.5$ \\
Good & $57.6-74.7$ \\
Very Good & $74.8-92.0$ \\
\hline
\end{tabular}

Table 2. Categories of MCQs for Conceptual Understanding

\begin{tabular}{cc}
\hline Category & Conceptual Understanding \\
\hline Very Not Good & $25.0-43.7$ \\
Not Good & $43.8-62.5$ \\
Good & $62.6-81.2$ \\
Very Good & $81.3-100.0$ \\
\hline
\end{tabular}

During data collection (see figure 1), the first activity that must be done is to select students based on the categories provided by the researcher, then give a questionnaire of learning motivation and MCQs to break students' concepts in learning social science (geography, sociology, economy, and history), the questionnaire is then processed using SPSS 21 application data to see descriptive statistics, in the form of, the mean, min, max, percentage, and category of students and see if there is an impact between the two variables.

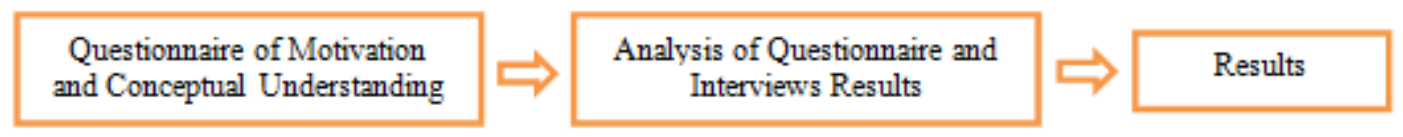

Figure 1. Data Collection 


\subsection{Analyze Data}

All data was obtained from the motivation questionnaire and MCQs to understand student concepts on student values and collected and calculated and assisted with the SPSS 21 application. Descriptive statistics are given to calculate the frequency, percentage, mean, min, and max of a sample [30]. In this study, quantitative data was analyzed using parametric statistics from simple regression to determine whether there was an impact between student learning motivation and understanding students' learning concepts. This study uses SPSS 21 at a significance level of 0.025 and is followed by interviews used to strengthen the quantitative data results.

\section{Results}

Cognitive and affective aspects are very important for students to have in education today. Because, by having functional affective aspects, it will affect the affective aspects of a student [34-36]. Therefore the renewal of this research is how students' understanding concepts in learning, social science (geography, sociology, economy, and history) can influence students' motivation, where you can see the results of the study (Table 3-6).

\subsection{Motivation}

The results of the student motivation questionnaire can be seen in table 3 .

From table 3, which came from 600 respondents from the Madrasah Ibtidaiyah (Islamic elementary school) in Bengkulu, 300 for rural and 300 for urban after they were obtained and the results obtained using the SPSS 21 application program, the learning motivation of students in urban having a dominant for rural was category a good, with a percentage of $71.0 \%$ for 213 students out of 300 students. The lowest category is not very good at $1.0 \%$ for 3 students out of 300 total students. From 300 students, the mean results were 62.5 , the maximum score was 89 , and the minimum value was 31 ., and for rural was category a not good, with a percentage of $65.0 \%$ to 195 students for 300 total students. The lowest category is very good at $2.3 \%$ for 7 students out of 300 students. From 300 students, the mean results were 48.3 , the maximum score was 78 , and the minimum value was 22 .

The results of the questionnaire analysis in table 2, on student motivation, have good results of $68.8 \%$ (413 out of 600) students in social science subjects. This is indicated by the interaction between the teacher and students, and the teacher wants to discuss the lesson outside of class hours. This can also be seen from the results of the interviews conducted.

"When you have difficulty in learning, what does your teacher do?"

"My teacher provides support by motivating me, so that I am able to do it."

Table 3. Results of student motivation questionnaires

\begin{tabular}{|c|c|c|c|c|c|c|c|c|c|}
\hline & \multicolumn{5}{|c|}{ Classification } & \multirow{2}{*}{ Mean } & \multirow{2}{*}{ Min } & \multirow{2}{*}{ Max } & \multirow{2}{*}{$\%$} \\
\hline \multirow{6}{*}{$\begin{array}{l}\text { Rural } \\
\text { Areas }\end{array}$} & Interval & Category & $\mathrm{M}$ & $\mathrm{F}$ & Total & & & & \\
\hline & $23.0-40.2$ & Not very good & 39 & 12 & 51 & \multirow{4}{*}{48.3} & \multirow{4}{*}{22} & \multirow{4}{*}{78} & 17.0 \\
\hline & $40.3-57.5$ & Not good & 115 & 80 & 195 & & & & 65.0 \\
\hline & $57.6-74.7$ & Good & 26 & 21 & 47 & & & & 15.7 \\
\hline & $74.8-92.0$ & Very good & 2 & 5 & 7 & & & & 2.3 \\
\hline & \multirow[t]{2}{*}{ TOTAL } & & 182 & 118 & 300 & & & & 100 \\
\hline & & \multicolumn{4}{|c|}{ Classification } & & & & \\
\hline \multirow{6}{*}{$\begin{array}{l}\text { Urban } \\
\text { Areas }\end{array}$} & Interval & Category & M & $\mathrm{F}$ & Total & ivitant & IVIII & NIax & $\%$ \\
\hline & $23.0-40.2$ & Not very good & 2 & 1 & 3 & \multirow{4}{*}{62.5} & \multirow{4}{*}{31} & \multirow{4}{*}{89} & 1.0 \\
\hline & $40.3-57.5$ & Not good & 24 & 8 & 32 & & & & 10.7 \\
\hline & $57.6-74.7$ & Good & 126 & 87 & 213 & & & & 71.0 \\
\hline & $74.8-92.0$ & Very good & 30 & 22 & 52 & & & & 17.3 \\
\hline & TOTAL & & 182 & 118 & 300 & & & & 100 \\
\hline
\end{tabular}




\subsection{Conceptual Understanding}

From the results of the questionnaire, an understanding of student concepts can be seen in table 4 .

From table 4, which came from 600 respondents from the Madrasah Ibtidaiyah (Islamic elementary school) in Bengkulu, 300 for rural and 300 for urban after they were obtained and the results obtained using the SPSS 21 application program, the learning motivation of students in urban having a dominant for rural was category a good, with a percentage of $76.6 \%$ for 230 students out of 300 students. The lowest category is not very good at $1.3 \%$ for 4 students out of 300 total students. From 300 students, the mean results were 75.5 , the maximum score was 96 , and the minimum value was 31 , and for rural was category a not good, with a percentage of $60.7 \%$ to 182 students for 300 total students. The lowest category is very good at $3.3 \%$ for 10 students out of 300 students. From 300 students, the mean results were 51.5 , the maximum score was 85 , and the minimum value was 28 .

"When you are directly asked by the teacher how do you respond?"

"I immediately answered what was asked by my teacher in a straightforward and confident manner."

"How can you answer the question from your teacher straightforwardly and confidently?"

"Because I have understood the concepts in the learning."

\subsection{The Regression}

For the results of the influence of motivation on students' understanding of concepts in learning, social science can be seen in table 5 .

Table 4. Results from the questionnaire understanding students' concepts in learning social science

\begin{tabular}{|c|c|c|c|c|c|c|c|c|c|}
\hline & \multicolumn{5}{|c|}{ Classification } & \multirow{2}{*}{ Mean } & \multirow{2}{*}{ Min } & \multirow{2}{*}{ Max } & \multirow{2}{*}{$\%$} \\
\hline \multirow{6}{*}{$\begin{array}{l}\text { Rural } \\
\text { Areas }\end{array}$} & Interval & Category & & & Total & & & & \\
\hline & $25.0-43.7$ & Not very good & 42 & 12 & 54 & \multirow{4}{*}{51.5} & \multirow{4}{*}{28} & \multirow{4}{*}{85} & 18.0 \\
\hline & $43.7-62.5$ & Not good & 117 & 65 & 182 & & & & 60.7 \\
\hline & $62.6-81.2$ & Good & 19 & 35 & 54 & & & & 18.0 \\
\hline & $81.3-100.0$ & Very good & 4 & 6 & 10 & & & & 3.3 \\
\hline & \multirow[t]{2}{*}{ TOTAL } & & 182 & 118 & 300 & & & & 100 \\
\hline & & \multicolumn{4}{|c|}{ Classification } & \multirow{2}{*}{ Mean } & \multirow{2}{*}{ Min } & \multirow{2}{*}{ Max } & \multirow{2}{*}{$\%$} \\
\hline \multirow{6}{*}{$\begin{array}{l}\text { Rural } \\
\text { Areas }\end{array}$} & Interval & Category & & & Total & & & & \\
\hline & $25.0-43.7$ & Not very good & 3 & 1 & 4 & \multirow{4}{*}{75.5} & \multirow{4}{*}{31} & \multirow{4}{*}{96} & 1.3 \\
\hline & $43.7-62.5$ & Not good & 14 & 6 & 20 & & & & 6.7 \\
\hline & $62.6-81.2$ & Good & 138 & 92 & 230 & & & & 76.6 \\
\hline & $81.3-100.0$ & Very good & 27 & 19 & 46 & & & & 15.4 \\
\hline & TOTAL & & 182 & 118 & 300 & & & & 100 \\
\hline
\end{tabular}

Table 5. Results of Regression

\begin{tabular}{|c|c|c|c|c|c|}
\hline \multirow{2}{*}{ Variable } & \multicolumn{2}{|c|}{ Unstandardized Coefficients } & Standardized Coefficients & t & sig. \\
\cline { 2 - 6 } & B & Std. Error & Beta & & \\
\hline 1 (Constant) & 12.199 & 3.148 & & 4.572 & .000 \\
\hline Conceptual Learning & .112 & .121 & .128 & 1.491 & .014 \\
\hline
\end{tabular}


Table 5 shows the results of a simple regression test found that the regression equation is $\mathrm{Y}=12.199+0.112 \mathrm{X}$. The number of contributions from motivation in understanding student concepts can be seen in Table 6 below.

Table 6. Contribution to understanding student concepts of motivation

\begin{tabular}{|c|c|c|c|c|}
\hline Model & R & R square & $\begin{array}{c}\text { Adjust R } \\
\text { Square }\end{array}$ & $\begin{array}{c}\text { Std. Error of } \\
\text { the Estimate }\end{array}$ \\
\hline 1 & .809 & .725 & .712 & 2.719 \\
\hline
\end{tabular}

The result of simple regression analysis shows (table 6) that the coefficient of determination is $\left(\mathrm{R}^{2}\right) 0.725$. This means that the contribution of students' understanding of concepts on motivation is $72.5 \%$, while other variables influence the remaining $27.5 \%$.

\section{Discussion}

In essence, the concepts that exist in an individual's cognitive structure are the result of the experience he has gained; thus, the concepts that an individual has are the result of the learning process. The results of the learning process will be the foundation in the structure of individual thinking. Moreover, these concepts are the basis for someone in solving problems, knowing the relevant rules, and other things that have to do with what someone must do expressing through attitude/behavior/action [37, 38]. Examples of learning outcomes in the cognitive domain are conceptual understanding of learning topics that are owned by students. Understanding the concept is very important in learning social science. Understanding of concepts in social science is one of the abilities that students must possess and develop. This explains that it is not just rote learning in social science, but understanding concepts need to be considered. In learning activities, it is essential to create a condition or process that directs students to carry out learning activities. In this case, of course, the teacher's role is significant $[39,40]$ how teachers make efforts to be able to grow and provide motivation so that students do learning activities well. To be able to learn well requires a good process and motivation too. That is why educational psychologists began to pay attention to good motivation $[41,42]$. In this case, it is necessary to emphasize that motivation is never said to be good if the desired goal is not good.

Meanwhile, motivation is the active driving force of someone who is intrinsical to take any action to achieve goals or meet needs. Motivation is a process that energizes, directs, and maintains behaviour [43]. Learning, motivation can arise due to intrinsic and extrinsic factors. One of the extrinsic factors is a conducive learning environment. Conducive means truly supporting the continuity of the learning process. The atmosphere when the learning process can affect the efficiency of learning time with a less conducive atmosphere will make students not focus on the learning process so that learning time is not effective [44, 45]. In line with this, Hidi explained that a conducive environment is a driving factor that attracts the learning process. In contrast, an unpleasant environment will lead to boredom and boredom [46, 47]. Teachers and parents who always set a good example for children, social friends who provide positive life lessons, a place where learning is calm, and complete learning tools can increase student motivation.

Motivation is a series of efforts to provide certain conditions so that someone wants to do something $[48,49]$. In learning activities, motivation plays as a driving force in students that creates a desire for learning, which ensures the continuity of learning activities and provides direction for learning activities, so that the desired subject objectives are achieved $[50,51]$. Students who have strong motivation will have a lot of energy to carry out learning activities. Motivation will be stimulated if a pleasant classroom atmosphere, sufficient class size, the freedom to move, light and good air circulation will stimulate student learning motivation according to ability $[52,53]$. This means that schools and classrooms need to be appropriately managed and create a learning climate that supports learning. Astalini (2019); Maison (2019), stated that lack of motivation would cause students to lack enthusiasm in learning $[54,55]$.

In the learning process, the most important thing is achieving goals so that students can understand something based on their learning experiences [56, 57]. The ability to understand is fundamental because understanding will be able to achieve procedural knowledge. Comprehension is part of the cognitive domain regarding intellectual learning outcomes and is higher than knowledge [58]. Understanding is the basis for students to build insights. In social Science, learning places more emphasis on concepts. This means that in social studies learning students must first understand the concept of social studies to solve problems and be able to apply the learning in the real world $[59,60]$. Understanding the concept is very important because mastering the concept will make it easier for students to learn social studies material. In every learning effort, the emphasis is on mastering concepts to have an excellent essential provision to achieve other necessary skills such as reasoning, communication, connection, and problem-solving.

Sufficient motivation when learning something can generate interest in what is being learned, and this can bring children more in-depth into the subject in question. That learning and motivation have a significant influence on students' mastery of concepts, because if the material being studied is not under student learning motivation, then students will not learn optimally. Therefore, it can be said that student motivation affects students' mastery of concepts. Butler \& Lumpe (2008) stated that motivation is necessary for the learning process because someone who does not have the motivation to learn will not be able to 
carry out learning activities [61]. Furthermore, Djamarah stated that motivation is the fundamental driving force that encourages someone to learn. Motivation is a driving force that can give birth to activities for someone. Without motivation, someone will not do learning activities. Amin \& Qina (2018) state that students' mastery of concepts is used to solve a problem that has something to do with the concept they have [62]. Students' mastery of concepts is not limited to just knowing, but students must be able to connect one concept to another. To master new concepts, initial concepts are needed, obtained from daily experiences in various aspects of knowledge [62]. The concept is the main subject that underlies the whole as a result of abstract human thinking about objects, events, facts that explain many experiences. Only with the help of concepts can the teaching and learning process be maximized. The relevant concepts already exist in the cognitive structure of students.

The concepts that students already have will be more reliable if they are strengthened by new knowledge gained from actual experiences. Students will quickly obtain and understand the concepts if they can load their concept maps through real experience. Besides, the use of a science-based learning model can maximize the mind mapping method. However, teachers must have an understanding of mind mapping, and there must be innovations in learning to be able to increase student motivation and understanding. Using science-based models such as project-based learning, problem-based learning, and inquiry, they can think critically, think at a high level, be independent, and find information that is following what is needed so that it is under the objectives of the curriculum, namely student-based learning. He further added that the essence of inquiry learning is to manage students' conditions or learning environments with sufficient guidance in finding scientific principles and concepts. Emphasizing the five essences of inquiry (essential features of inquiry), namely; (1) Asking questions of a scientific nature; (2) Give priority to scientific evidence; (3) Formulating an explanation, (4) Linking the explanation with scientific knowledge; (5) Communicating and justifying scientific explanations.

Meanwhile, PBL is learning that has the essence of presenting various authentic and meaningful problematic situations to students, which have implications for decisions that can be taken by principals and vice-principals by applying learning methods such as inquiry, problem-based learning, and project-based learning. This must also be supported by teaching staff who must-have innovation in learning. That requires facilities and infrastructure such as information and communication technology, books, study desks that must be facilitated so that they have the motivation and have proper mind mapping because they do not. All children with mind mapping abilities will learn. Therefore, we need innovation from the teacher in teaching.

\section{Conclusions}

From the explanation that the researcher has done, the results show that the learning motivation of the students plays a role in understanding the concept of students in the material, especially in the social study material. This mind mapping can solve existing problems, students are lazy, and students do not have a critical and coherent understanding, one of the solutions is using mind mapping, because by using mind mapping students have a continuous and continuous way of thinking. With good motivation, students have willingness from within the individual, and from outside the individual students to deepen a material, students who have good motivation will be severe in looking for information about the material they want to explore in detail so that students can make maps the concept itself. This is also evidenced by the effect shown by the sig value below 0.025 , and there is a contribution of student conceptual understanding of motivation by $72.5 \%$. Therefore, it is recommended to the principal and vice-principal in the curriculum field to urge teachers to provide innovation in their learning, and the teacher must understand the method so that the creation of student-centered learning is following the applicable curriculum.

\section{Acknowledgments}

Thanks to the whole school principal, who has permitted me to research his school. Moreover, all the teachers who helped during the study and all the respondents who had been willing to help me be sampled in this study, I thank you as much as possible.

\section{REFERENCES}

[1] A.Amin. Madrasah dan Pranata Sosial. At-Talim: Media Informasi Pendidikan Islam, vol. 13, no. 2, pp. 183-200

[2] Susbiyanto., D. A. Kurniawan., R. Perdana., \& C. Riyantoni. Identifying the mastery of research statistical concept by using problem-based learning. International Journal of Evaluation and Research in Education. 8(3), 461-469, 2019

[3] A. Amin. Pemahaman Konsep Abstrak Ajaran Agama Islam pada Anak Melalui Pendekatan Saintifik dan Isyarat Analogi dalam Alquran. Madania: Journal Kajian Keislaman, vol. 21, no. 2 , pp. $157-170$

[4] G. M. Sinatra. The "warming trend" in conceptual change research: The legacy of Paul R. Pintrich. Educational Psychologist, 40, 107-115, 2005.

[5] Astalini, D. A. Kurniawan., Darmaji, L. R. Sholihah., R. Perdana. Characteristics of Students' Attitude to Physics in Muaro Jambi High School. Humanities \& Social Science Reviews (HSSR), 7(2), 91-99, 2019 
[6] Asrial., Syahrial., D. A. Kurniawan., M. Subandiyo., N. Amalina. Exploring obstacles in language learning among prospective primary school teacher. International Journal of Evaluation and Research in Education (IJERE), 8(2), 249-254, 2019

[7] Syahrial., Asrial., D. A. Kurniawan., F. Chan., A. Hariandi., R. A. Pratama., P. Nugroho., R. Septiasari. The Impact of Ethnoconstructivism in Social Affairs on Pedagogic Competences. International Journal of Evaluation and Researcn in Education (IJERE). 8(3), 409-416. 2019.

[8] Maison., Syahrial., Syamsurizal., \& Tanti. Learning Environment, Students' Beliefs, And Self-Regulation in Learning Physics: Structural Equation Modeling. Journal of Baltic Science Education, 18(3), 389-403. 2019.

[9] R. Duit., \& D. F. Treagust. Conceptual change: A powerful framework for improving science teaching and learning. International Journal of Science Education, 25, 671-688, 2003. doi:10.1080/ 09500690305016

[10] Kennedy, R. E., Townsend, P. A., Gross, J. E., Cohen, W. B., Bolstad, P., Wang, Y. Q., \& Adams, P. Remote sensing change detection tools for natural resource managers: Understanding concepts and tradeoffs in the design of landscape monitoring projects. Remote sensing of environment, 113(7), 1382-1396, 2009.

[11] S. E. Mathiassen., \& J. Winkel. Physiological comparison of three interventions in light assembly work: reduced work pace, increased break allowance and shortened working days. International archives of occupational and environmental health, 68(2), 94-108, 1996.

[12] S. L. Britner., \& F. Pajares. Sources of science self-efficacy beliefs of middle school students. Journal of Research in Science Teaching, 43, 485-499, 2006. doi: 10.1002/tea.20131

[13] I. Jo., \& J. E. Hong. Effect of Learning GIS on Spatial Concept Understanding. Journal of Geography, 1-11.2020. doi:10.1080/00221341.2020.1745870

[14] I. A. Shibley., L. M. Jr, Milakofsky, D. S. Bender, and H. O. Patterson. College chemistry and Piaget: An analysis of gender difference, cognitive abilities, and achievement measures seventeen years apart. Journal of Chemical Education 80 (5):569-73, 2003. doi: 10.1021/ed080p569.

[15] S. K. Srivastava. Threshold concepts in geographical information systems: A step towards conceptual understanding. Journal of Geography in Higher Education 37 (3):367-84, 2013. doi: 10.1080/03098265.2013.775569.

[16] T. Oyana., S. Garcia, T. Hawthorne, J. Haegele, J. Morgan, and N. Young. Nurturing diversity in STEM fields through geography: The past, the present, and the future. Journal of STEM Education. 16 (2):20-9, 2015

[17] S. Edwards., \& N. Cooper. Mind mapping as a teaching resource. The clinical teacher, 7(4), 236-239, 2010.

[18] M. Davies. Concept mapping, mind mapping and argument mapping: what are the differences and do they matter? Higher education, 62(3), 279-301, 2011.

[19] J. L. Mohler. Using interactive multimedia technologies to improve student understanding of spatially-dependent engineering concepts. In Proceedings of the GraphiCon,
292-300, 2001.

[20] L. M. Madsen., \& C. Rump. Considerations of how to study learning processes when students use GIS as an instrument for developing spatial thinking skills. Journal of Geography in Higher Education 36 (1), 97-116, 2012. doi: $10.1080 / 03098265.2011 .576336$

[21] M. A. S. Pulaski. Understanding Piaget: An introduction to children's cognitive development, 1971.

[22] R. S. Weisskirch. Dealing with Piaget: Analyzing Card Games for Understanding Concepts, 2003.

[23] F. Turk., \& M. Calik. Using different conceptual change methods embedded within 5E model: A sample teaching of endothermic - exothermic reaction. Asia-Pacific Forum on Science Learning and Teaching, 9, 1-10, 2008.

[24] Astalini., Darmaji., D. A. Kurniawan., T. O. Puspitasari., A. Lumbantoruan., Y. E. Putri., N. Sari. Review of Educational Psychology: Attitudes towards Physics. Universal Journal of Educational Research, vol. 8, no. 3, pp. 1349-1403. 2020

[25] Astalini., Kurniawan, D. A., Sulistiyo, U., Perdana, R., Susbiyanto, S. E-Assessment Motivation in Physics Subjects for Senior High School. International Journal of Online and Biomedical Engineering (iJOE). 15(9), 4-15, 2019

[26] Syaiful., Kamid., Muslim., N. Huda. Investigate the relationship of creative thinking skills and junior high school students motivation. Humanities \& Social Science Reviews, $8(2), 159-167,2019$

[27] Maison, Darmaji, Astalini, D. A. Kurniawan, P. S. Indrawati. Science Process Skills and Motivation. Humanities \& Social Science Reviews (HSSR), 7(5), 48-56. 2019

[28] Guido, Ryan Manuel D. "Attitude and Motivation towards Learning Physics". International Journal of Engineering Research \& Technology, Vol. 2, No. 11, 2013, pp 2087-2094.

[29] D. M, Martens. Research And Evaluation In Education And Psychology Integrating Diversity With Quantitative, Qualitative, And Mixed Methods. Singapore: SAGE Publications Asia-Pacific 2010.

[30] J. W, Creswell. Research Design Qualitative, Quantitative, And Mixed Method Aproach. Singapore: SAGE Publications Asia-Pacific, 2012.

[31] F. N, Kerlinger. Foundations of behavioral research. Yogyakarta: Gadjah Mada, 2014.

[32] L. Cohen., L. Manion., \& K. Morrison. Research Methods in Education: Routledge. 2007

[33] M. B, Miles., \& A. M, Huberman. Qualitative data analysis (2nd ed.). Thousand Oaks, CA: Sage. 1994

[34] Astalini., D. A. Kurniawan., Darmaji., M. Ikhlas., Kuswanto., R. Perdana., L. Anggraini., I. Putra. Attitude and Self-confidence Students in Learning Natural Sciences: Rural and Urban Junior High School. Universal Journal of Educational Research. 8(6), 2569-2577, 2020.

[35] Syahrial., Asrial., L. G. Melinda., M. R. Fajar., N. Jannah., T. O. Puspitasari., Y. E. Putri. Impact E-Modul 
Ethnoconstructivism: Attitude \& Motivation. International Journal of Scientific \& Technology Research, vol. 9, no. 4, pp. 3752-3757, 2020.

[36] Maison., Ernawati, M. D. W., Budiarti, R. S., Kurniawan, W., Ningsih, Y., Puspitasari, T. O., Jannah, N., Putra, D. S. Learning in Nature Science: Social Implication, Normality of Scientist., Attitudes Towards Investigation of Natural Science, and Interest Adds To Science Learning Time. International Journal of Scientific \& Technology Research, 8(12), 1478-1484, 2019.

[37] Syahrial., Asrial., Husni, S., Arsil. Attitudes, Self-Confidence, and Independence of Students in Thematic Learning. Universal Journal of Educational Research. 8(1), 162-168, 2020.

[38] Budiarti, R. S., Harlis., Natalia, D. High Oder Thinking Skills for Biology Education: Applied Microbiology Learning Videos Based on Jambi Local Wisdom. Universal Journal of Education Resaerch, 8(2), 689-694. 2020

[39] Syaiful., Kamid., Muslim., N. Huda. Emotional Quotient and Creative Thinking Skills in Mathematics. Unviersal Journal of Educational Research, 8(2), 499-507. 2020

[40] T. Susanti., Damris., Maison., Tanti. Learning environment and motivation in junior high school. Universal Journal of Educational Reseaerch. 8(5), 2047-2056. 2020

[41] Arandia, E., Kristina Zuza, and Jenaro Guisasola. "Attitudes and motivations towards physics and its learning at both high school and university", International Journal of Education and Information Technologies, vol. 10, 2016, pp 58-65.

[42] Maison., Astalini., D. A. Kurniawan., R. Perdana., L. Anggraini. The Phenomenon of Physicology Senior High School Education: Relationship of Students' Attitudes towards Physics, Learning Style, Motivation. Universal Journal of Educational Research. 7(10), 2199-2207, 2019

[43] D. H. Uttal., \& C. A. Cohen. 4 Spatial thinking and STEM education: When, why, and how? Psychology of Learning and motivation-Advances in Research and Theory 57:147, 2012 .

[44] S. Kingir., Y. Tas., G. Gok., \& S. S, Vural. Relationships among constructivist learning environment perceptions, motivational beliefs, self-regulation and science achievement. Research in Science \& Technological Education, 31(3), 205-226. 2013. https://doi.org/:10.1080/0 2635143.2013.825594

[45] S. Velayutham., \& J. M. Aldridge. "Influence of Psychosocial Classroom Environment on students' Motivation and Self-Regulation in Science Learning: A Structural Equation Modeling Approach." Research in Science Education 43: 507-527. 2013

[46] S. Hidi., \& J. M, Harackiewicz. Motivating the academically unmotivated: A critical issue for the 21 st century. Review of Educational Research, 70(2), 151-179. 2000.

[47] M. Liu., D. Williams., \& S. Pedersen. Alien Rescue: A problem-based hypermedia learning environment for middle school science. Journal of Educational Technology Systems, 30(3), 255-270. 2002

[48] D. Stipek. Motivation to learn: From theory to practice.
Needham Heights, MA: Allyn \& Bacon. 1993

[49] K. Vaino., J. Holbrook., \& M. Rannikmae. Stimulating students' intrinsic motivation for learning chemistry through the use of contextbased learning modules. Chemistry Education Research and Practice, 13, 410-419, 2012. doi: $10.1039 / \mathrm{c} 2 \mathrm{rp} 20045 \mathrm{~g}$

[50] S. L, Knight., \& H. C, Waxman. Investigating the effects of the classroom learning environment on students' motivation in social studies. Journal of Social Studies Research, 14, 1-12. 1990.

[51] M. Liu. The Effect of a Hypermedia Learning Environment on Middle School Students' Motivation, Attitude, and Science Knowledge. Computers in the Schools, 22(3-4), 159-171. 2005. https://doi.org/:10.1300/j025v22n03_13

[52] H. C, Waxman., \& S. Y. L, Huang. Motivation and Learning Environment Differences in Inner-City Middle School Students. The Journal of Educational Research, 90(2), 93102.

1996. https://doi.org/:10.1080/00220671.1996.9944450

[53] P. A. Story., J. W. Hart., M. F. Stasson., \& J. M. Mahoney. Using a two-factor theory of achievement motivation to examine performance based outcomes and self-regulatory processes. Personality and Individual Differences, 46, 391395, 2009.

[54] Astalini., D. A. Kurniawan., U. Sulistiyo, U., R. Perdana., S. Susbiyanto. E-Assessment Motivation in Physics Subjects for Senior High School. International Journal of Online and Biomedical Engineering (iJOE). 15(9), 4-15. 2019.

[55] Maison., Ernawati, M. D. W., Budiarti, R. S., Kurniawan, W., Ningsih, Y., Puspitasari, T. O., Jannah, N., Putra, D. S. (2019). Learning in Nature Science: Social Implication, Normality of Scientist., Attitudes Towards Investigation of Natural Science, and Interest Adds To Science Learning Time. International Journal of Scientific \& Technology Research, 8(12), 1478-1484.

[56] T. A. Grotzer., \& S. L. Solis. Action at an attentional distance: A study of children's reasoning about causes and effects involving spatial and attentional discontinuity. Journal of Research in Science Teaching 52 (7):1003-30, 2015. doi: $10.1002 /$ tea.21233.

[57] A. Cetin-Dindar., \& O. Geban. Conceptual understanding of acids and bases concepts and motivation to learn chemistry. The Journal of Educational Research, 110(1), 85-97, 2016.doi:10.1080/00220671.2015.1039422

[58] Haryanto., Asrial., M. D. W. Ernawati. E-Worksheet for Science Processong Skills Using Kvisoft Flipnook. International Journal of Online and Biomedical Engineering, 16(3), 46-59, 2020

[59] S. Everett. Spatial thinking strategies. Science and Children 37 (7): 36-48, 2000.

[60] E. Geist, E. Let's make a map: The developmental stages of children's mapmaking. YC Young Children 71 (2), 50, 2016.

[61] K. A, Butler., \& A. Lumpe. Student use of scaffolding software: Relationships with motivation and conceptual understanding. Journal of Science Education and Technology, vol. 17, no. 5, pp. 427-436, 2008. 
[62] M. Amin., \& Q. A. Hina. Effect of Mind Mapping Technique on Student Intrinsic Motivation at Higher
Education Level. Journal of Research and Reflections in Education, vol. 12, no. 2, pp. 296-313, 2018 